\title{
Between crises and insurgencies: the political ecology in defense of shared living
}

\author{
Vanessa Lucena Empinotti \\ Sue A. S. lamamoto \\ Isabella Lamas \\ Felipe Milanez
}

${ }^{I}$ Federal University of ABC, São Bernardo do Campo, SP, Brazil.

${ }^{\text {II }}$ Federal University of Bahia, Salvador, BA, Brazil.

D III University for International Integration of the Afro-Brazilian Lusophony, São Francisco do Conde, BA, Brasil.

IV Federal University of Bahia, Salvador, BA, Brasil.

\begin{abstract}
This article offers a review of the recent trajectories of political ecologies as communities of practice and movements for environmental justice, as well as a paradigm of scientific analysis. In this introduction to the 2021 special issue "Decolonial Insurgencies and Emancipatory Horizons: contributions from Political Ecology" of the Ambiente \& Sociedade journal, we present a reflection on the contemporary socioenvironmental reality, characterized by crises, environmental destruction, and climate emergency, focusing on the role of political ecology as a privileged space to critically discuss the socio-environmental relations that constitute new forms of violent appropriation of nature. Facing the tension of the current context marked by the rise of phenomena such as authoritarianism, climate change denial, and inequality, we highlight the construction of counter-narratives and alternatives that mobilize other horizons of emancipation and living projects through insurgencies and movements that emerge from the protagonism of marginalized populations and struggles for environmental justice.
\end{abstract}

Keywords: Political ecology; decolonial thinking; socio-environmental relations; appropriation of nature; resistance

São Paulo. Vol. 24, 2021

Debating Ideas: Decolonial Insurgences and Emancipatory Horizons

DOI: http://dx.doi.org/10.1590/1809-4422asoc20210160vu2021L5ID 


\section{Introduction}

In March 2019, at the Federal University of Bahia, the III Latin American Congress of Political Ecology was organized to discuss decolonial insurgencies and emancipatory horizons from the perspective of political ecology. Around a thousand people, including activists, academics, researchers, and leaders of traditional peoples in Latin America shared a unique opportunity for exchange, reflection, and communion of knowledge and experiences. At that moment in Brazil, the pressure on traditional territories was already increasing, and there was an intensification of violence against the leaders who resisted those advances such as tourism-, agriculture-, mining- and water-related enterprises, among others. At the same time, the articulation of conservative sectors was also marked in the undermining of the existing environmental policies and of the state's role of safeguarding the rights of traditional and vulnerable populations.

Since then, several environmentally damaging actions have been taken in many parts of the world. In Brazil, we have witnessed the collapse of environmental institutions through the dismantling of the Ministry of the Environment and its autarchies, with the "droving of the cattle" - that is, letting infra-legal regulations go through, taking advantage of the pandemic tragedy to deregulate the environmental protection system (VALE et al. 2021); the cuts in funding aimed at deforestation control, research and monitoring (ASCEMA, 2020); and the questioning, by the current Brazilian government, of the INPE (National Institute for Space Research) monitoring reports, which indicated an increase in fires and deforestation in the Amazon. This disarticulation and the redefinition of the role of the state and the private sector, nationally and internationally, increased the violent occupation of public areas and territories of indigenous and traditional populations, which led to an increase in the number of conflicts in recent years (CPT, 2020). At the same time, extreme events have become increasingly frequent, raising awareness that we are living in a period of a climate emergency that demands immediate action. The last report of the Intergovernmental Panel on Climate Change (IPCC), published in August 2021, was deemed by the UN Secretary General "a code red for humanity", as it presents irrefutable scientific evidence of the climate emergency (UN, 2021).

The disputes over natural resources include new exploitation practices, sometimes pushed by authoritarian governments and climate change denial interest groups that have consolidated in various parts of the world, particularly in Brazil. Thus, new dynamics of environmental violence, exploitation, and control perpetuate the separation between human and non-human beings, legitimize the super-exploitation of natural resources, characterizing our planet's current situation, as well as the condition of environmental collapse in which we find ourselves.

In this sense, political ecology and its critical analysis of the socio-natural relations that build our reality have a key role in exposing the processes, dynamics, and consequences of degradation and violence present in the practices of transformation and production of nature, as well as in countering this reality and pointing toward new paths. In this perspective, the environment is construed as a conflicted field, where environmental degradation is a consequence of the expansion of the Development model (ESCOBAR, 
1995), emerging from the perpetuation of colonial relations of exploitation, appropriation, dispute over and control of natural resources to the detriment of traditional and/ or marginalized populations (ALIMONDA, 2011; LEFF, 2021; PEET; WATTS, 2004). Thus, political ecology reveals that the environmental collapse is not just a biological, geophysical, technical, or bureaucratic problem. By taking into account the political economy of the processes of occupation, appropriation, and modernization resulting from the hegemonic capitalist development model effected against the environment or by analyzing the production of knowledge and power flows that inform the control, transformation, and degradation of the environment, political ecology stands out as a privileged space for understanding the magnitude of the environmental collapse we are experiencing, marked by processes of violent appropriation of nature, and the increase in socio-environmental inequalities (BUNKER, 1985; HETCH, 1985).

From this perspective, political ecology points to emancipatory horizons based on new productive and reproductive processes, which should be contextualized in terms of justice, recognition of the other, different knowledges, and diverse understandings of the world (ACSELRAD, 2009; LEFF, 2021). This reflection seeks to ground the construction of another reality upon new relations between humans and non-humans in a decolonial and post-colonial perspective (ESCOBAR, 1995; ROCA-SERVANT; PERDOMOSÁNCHEZ, 2020; ALIMONDA et al., 2017).

The first goal of this article is to introduce the special issue "Decolonial Insurgencies and Emancipatory Horizons: contributions from Political Ecology" of the Ambiente $\mathbb{E}$ Sociedade journal, which publishes the discussions that took place at the III Latin American Congress of Political Ecology. However, we also propose here a broader reflection about the socio-environmental reality, its dynamics, processes, conflicts, and resistances, and about the role of political ecology in making these problems visible while, at the same time, contributing to the construction of counter-narratives that build other horizons of emancipation and life projects. As such, this text is organized in four parts, in addition to this introduction. In the first part, we examine the global context and the new dynamics that contextualize environmental struggles, such as authoritarianism, the denial of climate change, and the growth of social inequality. Next, we present and discuss how contemporary structures of domination work in the reproduction and creation of new forms of exploitation and control of nature. In the third part of the article, we analyze the response to the current context through the constitution of counter-narratives, pushed forward by the mobilization of native and traditional populations, but also women, urban social movements, and others, who reassess their resistance and re-existence in the face of new forms of violence, dispossession, and revaluation of their territories, often already formally recognized. Finally, we conclude the article by presenting some reflections and challenges involved in the construction of another plural, multi-universal reality, able to recognize multiple ways of living and being. 


\section{Environmental collapse, authoritarianism, science denial, and inequality}

Characterized by the expansion of neoliberalism, the crisis of welfare states, science denial and the rising authoritarian movements (BROWN, 2019; DANOWSKI, 2020; MILANEZ, 2020; NEIMARK et al., 2019), the current global context calls for a deeper critical analysis of the contemporary environmental degradation. Such global political rearrangement is intensely imbricated into the environmental collapse we are experiencing.

The recognition of the limits of the planet brought about by climate change has placed the environmental issue in a central position in geopolitical dynamics, as the dominant sectors of global capitalism have found themselves truly threatened in their instrumental relationship with nature. In response, as Latour (2019) argues, most of these sectors refused to pay for the "volte-face" of the Earth. The evident selfishness of this solution could only be transformed into a hegemonic ideology, of massive and global reach, if the environmental collapse was denied. It was necessary to convince humanity - despite all evidence - that there was no climate change and that the capitalist development model was, as it had always been, the best and only way. Thus, a new phase of violent exploitation is inaugurated, driven by science denial and "post-truth", where new mechanisms and actors join the scenario guided by a total indifference to facts (NEIMARK, et al., 2019).

This strategy is sometimes translated into a nationalistic and xenophobic language that exalts isolation and protection against immigrants and international organizations. On the other hand, marked by immediacy and a disregard for the future, this strategy also promotes lax legislation enforcement, facilitating a new wave of exploitation of nature and its territories (LATOUR, 2019).

For Latour (2019), this has resulted in a triple movement that coincides with the expansion of the neoliberal model in the world: the explosion of inequalities, deregulation, and climate change denial. The erosion of welfare states, the multiplication of private fortresses and walls, the commodification of nature and social relations: all these elements contribute to the breakdown of bonds of solidarity and mutual responsibility with shared living on Earth (NAVARRO; GUTIÉRREZ, 2018). Thus, the neoliberal model, by denying solutions that emerge from political and social life and promoting private and family-centered solutions (BROWN, 2019), frontally attacks any joint attempt to confront the climate emergency.

In the Latin American context, those dynamics take place on top of previous processes of exploitation and violent appropriation of nature, which have been a reality since the wars of conquest and the colonial period and continue to this day (ALIMONDA, 2011; PÁDUA, 2002; MILANEZ; SANTOS, 2021). Here, centuries-old relations of domination and control are perpetuated through the reinvention of structures of exploitation and violence, intensifying the processes of inequality, disrespect, and the imposition of a single reality. Environmental degradation goes far beyond its biophysical dimension, almost systematically entailing the violation, destruction, and oppression of native and traditional populations, understood as obstacles to development. Thus, consumption chains and the production of wealth on a global scale generate transformations 
on a regional and local scale, redefining territories as spaces of dispute, resistance, and re-existence (PORTO-GONÇALVES; LEFF, 2021; ALIMONDA, 2017).

\section{Domination structures and new practices of appropriation of nature}

The global political context described above is sustained by structures of domination that provide a new wave of exploitation and revaluation of nature. Processes of commodification, privatization, and financialization redefine productive practices and the expansion of capitalism. They perpetuate the peripheric condition under capitalist modernity, by which Latin American countries have been placed in a "global division of nature" - the "material foundation for the international division of labor" (CORONIL, 1997, p. 29) - laden with providing raw materials and cheap labor for global capitalist development.

Thus, the access to and the supply of natural resources are mediated by different practices that are transformed over time but maintain their exploitative drive. We can observe such transitions when analyzing, for example, the genealogy of Latin American mining. Machado Aráoz (2020) locates in Potosí, a silver whose exploitation started by the Spanish in 1545 continues in Bolivia until today, the origin of the extractive model in the region, characterized by keeping "devastation as a principle". Like other extractivisms, mining was marked by the tripod "genocide-ecocide-epistemicide" (MACHADO ARAÓZ, 2020), contaminating soils with mercury and other waste, subjugating native populations with forced labor, and eliminating pre-colonial systems of social and territorial organization.

Those long-term structures inherited from colonialism, which have placed the continent in the international division of nature, are reflected in the more recent extractive cycle that has accompanied the commodities boom in the first decades of the twenty-first century (DEONANDAN; DOUGHERTY, 2016). Latin America becomes, in this context, a preferential space for the expansion of global extractive industries, resulting in an intensification in the forms of extractivism - such as open-pit mining - and the increase in social and political conflicts resulting from it (BEBBINGTON, 2009). This process has been called "neoextractivism" by some authors, who conceive it as a development model based on the appropriation of nature and dependent on the export of natural resources at the international level, but also on a more active state role in the construction of new sources of social and political legitimation through the redistribution of extractive surpluses (GUDYNAS, 2009; ACOSTA, 2016).

The recent rise of authoritarian projects has brought new dynamics to extractivism, which now effects a blind bet on violently imposed depletion of resources, made possible by a complete dismantling of prior institutions of control. This new model is materialized by Jair Bolsonaro's government in Brazil, with its repeated attacks against indigenous people, human rights defenders, and environmentalists, and the deliberate dismantling of the Ministry of Environment and its agencies (VALE et al. 2021). In this government project, the instrumental relationship with nature characterized by extractivism and plunder is seen as a value in itself, not as a "necessary evil" in order to safeguard social policies. 
It is important to emphasize that the capitalist processes of re-signifying the commons and separating them from humans go beyond extractivism. The structures of domination that lead to environmental depletion and degradation are built through a wide variety of processes of commodification and privatization of nature. In this sense, urban contexts are also relevant spaces for analyzing those phenomena, since, under capitalism, urbanization is a result of the inequalities of access and rights that shape socio-natural relations (SWYNGEDOUW; KAIKA, 2014).

In the case of water, since the 1990s, the privatization of supply companies and the economic valuation of water have been proposed as a neoliberal solution to promote universal access to water through the market (BUDDS; MCGRANAHAN, 2003). By assuming the inefficiency of the state in guaranteeing water distribution and consumption, the neoliberal perspective presented decentralization and privatization as a way to promote development and economic growth. In this sense, water would be transformed into a commodity to be exploited and commercialized based on economic principles. This dynamic does not necessarily entail the extraction and export of raw materials, as it does in mining or food production. However, it creates opportunities for private companies, foreign and national, to occupy spaces previously controlled by the state and to expand wealth-generating avenues, which does not guarantee, however, the reduction of inequality and the universal right to water. Thus, this new exploitation practice drives our attention beyond the borders of the territories of traditional populations, since it also involves all those who access water in rural and urban spaces (BERNABEU; MARTÍN, 2019; BRITTO et al., 2016; EMPINOTTI et al., 2019). The consequences of this strategy further reinforce the unequal conditions of access to water among different parts of the population and their multiple intersections, underlining the vulnerability of women, Black, and poor populations, as well as the continued separation between the commons and humans.

At the same time, since the 2008 global crisis, natural resources have become investment assets, generating dynamics of financialization that have further separated the commons and humans (WORLD BANK, 2010; WOLFORD et al., 2017). These dynamics have introduced new meanings, actors, and strategies of wealth production, and accumulation into a new phase of accumulation by dispossession (HARVEY, 2005). From an international perspective, financialization also operates to consistently favor capital over labor and nature, adapting the discourse adopted by political actors to its agenda. In this sense, as Clark and Hermele (2013) point out, the discourse of sustainability more often leads to "neocolonial practices, accumulation by dispossession, and the hegemony of finance capital" than to "sustaining metabolic support systems and livelihoods of the poor" (p. 29). At the same time, the authoritarian discourse that denies climate change promotes a "national sovereignty" to exploit the country's natural resources and counter any international initiative for global environmental governance (HARMES, 2012).

Financialization is not limited to a speculative capital with no relation to the productive or material world, but is a process that reaches all spheres of capital reproduction and encroaches on nature through various processes: 1) extractive industries of 
mining or agribusiness that increase their income with speculation activities (CLARK; HERMELE, 2013);2) urban policies related to sanitation services and water supply that are commodified and start to operate through a financialized logic (KLINK et al. , 2020); 3) large territorial extensions acquired by pension funds that become objects of speculation, affecting the protection of collective rights both in the countryside and in the city (SAUER; LEITE, 2012; FAIRHEAD et al., 2012).

Finally, we also observe a realignment of the chains of investment, exploitation, and appropriation beyond the traditional North-South key, which challenges us to conceive of new axes of analysis. The complexity of the current global political economy logic of exclusion cannot be deciphered by dividing the world into familiar labels such as 'developed' and 'underdeveloped'. Environmentally destructive contemporary practices have very similar perverse consequences for the daily lives of people and places that are very different from each other. Therefore, the transversality of the phenomenon requires not only a reassessment of traditional North-South relations, but also an articulation of forms of resistance based on broad transnational movements and activisms.

\section{Ecologies of forms of resistance}

Political ecology highlights the socio-natural relationships emerging from, on one hand, the structures of domination and predatory exploitation of nature, and, on the other, the dynamics of conflict and forms of resistance (PEETS; WATTS, 2004; ALIMONDA et al., 2017; SVAMPA, 2019). In this sense, in contrast with a negative understanding of socio-environmental conflicts, it conceives them as a struggle for the control of and access to natural resources, against dispossession and in defense of traditional forms of territorial occupation and living. Hence, conflict is understood as an "expression of restlessness; it is not the factor that generates dissonance, imbalance, and death. On the contrary, conflict is precisely the estrangement, the understanding and the exposure of segregation and death structures and the affirmation of life" (CPT, 2020, p. 7).

The high incidence of socio-environmental conflicts, associated with the 'colonization of nature' and the peripheral regional territorial integration in the global economy leading to environmental degradation and impoverishment (ALIMONDA, 2011), reveals not only violence against populations and the environment, but also the dynamics of resistance at the international level. The global peripheries are sites of confrontation by populations in defense of their territories against the expansion of the frontiers of natural resource exploitation. They are peripheries because the exploitation of their natural resources drives the production of wealth in industrial and consumption centers, but they can also be conceived as centers of the struggle against environmental violence and international dispossession practices (MARTÍNEZ-ALIER; MILANEZ, 2016, p.13). Thus, political ecologies also emerge from a decolonial perspective, from the understanding of international dependency relations and their contemporary reconfigurations.

Faced with this growing socio-environmental violence perpetrated by states and private actors in Latin America and other regions of the world, new ecologies of resistance are emerging from agroecology (GIRALDO; ROSSET, 2017), from ecofeminism 
(BARCA, 2020), from the right of communities to say no to extractivism (MALERBA, 2014), from the articulation between Black and indigenous populations, among others. Together, these ecologies are driven by the recovery of the collective and the construction of a common life.

Environmental degradation, as well as the accelerated transformation of the commons into natural resources in the last decades, challenged the prevailing capitalist model not only in terms of social justice and inequality, but also in terms of existence (LEFF, 2021; GORZ, 2006; ROCA-SERVANT; PERDOMO-SÁNCHEZ, 2020). Changing the development model has become not only an ethical proposition, but also a survival imperative. It would be necessary to redistribute, but also to slow down, to stop, and even to "go backward" or decrease.

The environmental collapse threatens the civilizing project of modernity based upon the anthropocentric ideal of domination of nature by humans (PORTO-GONÇALVES; LEFF, 2021). In this sense, this is also the crisis of the modern colonial world model that has operated for five centuries a combined logic of genocide, epistemicide, and ecocide, in which the destruction of knowledge (other than that of the dominant paradigm of science) goes hand in hand with the destruction of human beings and the environment (GROSFOGUEL, 2016; MACHADO ARÁOZ, 2020). For Porto-Gonçalves and Leff (2021), the disputes around the social construction of a sustainable future require, from the political ecology perspective, the deconstruction of theories and practices that underlie and enable the expansion of dominant strategies of appropriation of nature, grounded on emancipatory practices that lead to the reappropriation of nature and the reinvention of its territorialities. The experiences of vulnerable peoples and the articulation of socio-environmental movements in Latin America and elsewhere play a central role in the construction of alternatives. While emancipatory practices are important, it is also fundamental to emphasize the epistemic dimension of other cosmologies in the struggle for the construction of legitimate ways of existing and in the autonomous production of knowledge.

In recent years, marginalized populations suffering the consequences of environmental collapse and the processes of violence that intensified with the authoritarian movements have played an expanding role. As bearers of "alternative visions of relations with nature" (ALIMONDA, 2015, p. 161), these populations' existence is entangled with their territories. In the words of Chico Mendes, "there is no defense of the forest without the forest peoples." Indigenous leader and intellectual Ailton Krenak, when asked how he would update his emblematic speech at the National Constituent Assembly in 1987, said: "we are no longer sleeping on mats on the ground and living in houses covered with straw, watching the history from the margins. We have invaded history" (KRENAK; BOLOGNESI, 2021, p. 240). The idea of the invasion of history brought by Krenak can be understood as a synthesis of this long struggle against epistemicide, genocide, and ecocide, which today gains increasing prominence and visibility.

The Articulation of Indigenous Peoples of Brazil (APIB) is leading an intensive international mobilization to reverberate its denunciations and claims of rights, filing a 
complaint, for the first time in history, against a Brazilian president before the International Criminal Court for genocide and ecocide. Another symbolic example was a letter addressed to the new U.S. president, Joe Biden, and his special advisor for climate policy, John Kerry, in March 2021, denouncing the dismantling of environmental agencies carried out by the federal government and defending the inclusion of indigenous peoples "at the table, negotiating and elaborating strategies" for the protection of the Amazon (APIB, 2021, p.3). Through this letter, APIB simultaneously challenges the totalizing narrative on the nation-state of political modernity, which ignores the coercive integration of many populations into its space, and places indigenous peoples as central global political actors in the struggle against environmental collapse.

Along similar lines, the four narratives in this special issue, bringing forward the voices of leaders of traditional populations, resistance groups, and ecofeminists, are representative of the world's epistemic diversity and the protagonism of populations engaged in the struggles in defense of life and in the reinvention and dispute of meanings of their territorialities. This diversity is expressed, for example, through the movements of environmental and popular struggles led by women who articulate themselves to creatively denounce the inequal cost of environmental degradation. Ecofeminist struggles draw from the ethics of care to counter the current environmental collapse and are a fundamental part of the multiple possible forms of resistance on the basis of which we can conceive emancipatory horizons from the perspective of political ecology (NAVARRO; GUTIÉRREZ, 2018).

Finally, mobilizations for the right to access the commons are increasing not only in traditional territories, but also in urban areas. In this context, mobilizations against the transformation of water into a commodity, the privatization of supply systems, as well as their transformation into investment assets, join the struggle for the right to universal access to water and sanitation and become mobilizing agendas of resistance and struggle (CASTRO, et al., 2015). Activist networks such as ONDAS (National Observatory on the Right to Water and Sanitation), the Red Waterlat-GOBACIT and the network Ecología Política y Justicia Hídrica are spaces for mobilization, action, and scientific production that have recently played a significant role in highlighting water access injustice due to the Covid-19 pandemic, as well as in demanding action from the state and supply companies to counter this situation (FERRARA; EMPINOTTI, 2021; BOTERO-MESA et al., 2020).

\section{Political ecologies for a shared living}

Environmental struggles against the hegemonic model of exploitation of the Earth are expressed in a wide diversity of imaginative forms, which, by defending territories, denouncing environmental collapse, and fighting against colonial structures of domination, renew repertoires of collective action and propose alternative epistemic perspectives. As the surveys of the Environmental Justice Atlas or the Conflict Map of the Brazilian Environmental Justice Network reveal, environmental struggles compose an innovative, insurgent, and diverse global movement that differs from other institutionalized organi- 
zational forms (MARTINEZ-ALIER et al., 2016).

In this global framework of engagements in defense of shared living on the planet, the exploitation, plundering, and violence that have characterized Abya Yala, Nuestra América, since the invasion, have been deepened and accelerated in recent decades. Instead of caravels, the routes that make up the contemporary world-system are traced by immense cargo ships, followed by bytes transferring values from one country to another in the blink of an eye. The ecology of the world-system impacts the continent with a permanent expansion of the commodity frontiers, accelerating time and compressing space, removing barriers to the circulation of capital through the violent tripod of genocideecocide-epistemicide. The situation is one of permanent conquestality ${ }^{1}$ and coloniality that is constantly challenged by physical, epistemic and cosmopolitical ${ }^{2}$ resistances and rebellions in defense of the commons, whether in forests, villages or quilombos, in the countryside or in the cities, in all places of life where the violent forms of dispossession of capitalism are confronted.

The ecological system of capitalism loots human collectives in places of plunder, sacrificial zones, transport routes, tradescapes, and through the control of extraction infrastructure (BEBBINGTON et al., 2020), as well as in tailing ponds, through an unequal exposure to the effects of climate and ecological collapse in the countryside and in the city. For some time now, the counter-colonial resistance, as expressed by the quilombola intellectual Antonio Bispo (SANTOS, 2015), has warned that permanent accumulation is inconceivable for life on the planet. The degrowth movement, emerging in Europe, must have an anti-colonial character.

Let us remember the question of an old Tupinambá man to the French missionary Jean de Léry, in Guanabara in the sixteenth century: "Why do you French and Portuguese come from so far away looking for firewood to warm yourselves? Is there no forest in your countries?" When he learned that this was a sheer need for accumulation, he replied: "We have fathers, mothers and children whom we love; but we are sure that after our death the land that nourished us will also nourish them, so we rest unconcerned" (LÉRY, 2007, p. 169-170). It is the forest, the territory-life, that will provide the ecological conditions of existence for future generations. The legacy is not inheritance, but the place of life. There is an epistemic difference between this perspective and the one dominated by commodity and money.

The love for the land and the place, the will to stay in the territory, while realizing that the territory means life in multiple senses, is what prevents the Krenak, as Ailton Krenak explains, from leaving the shores of the Doce River even after the environmental crime of Mariana in 2015. The river is Watu, the old man, a relative. They do not want to leave the river that gives meaning to existence, just as they do not want to go to other planets, colonize Mars or the Moon: the Earth is the place of existence, and that is why

1 - Rita Segato defines the "conquestality of power" as a masculine mandate of territorial feudalization that has never ended, it is a racist and patriarchal historical project of private property (SEGATO, 2018).

2 - Isabelle Stengers, philosopher of Science, coined the term "Cosmopolitics" in her studies of the history of science (STENGERS, 2018). 
they express a deep love for the Earth. And this sense of belonging is not restricted to indigenous ontologies, but expands to life in community, to the collective and the common, as Krenak himself stresses, and refers to the place of origin, a place where it is possible to reproduce the collective experience of life (KRENAK, 2019).

Challenging the separation between nature and society, battling the creation of sacrificial zones, reconnecting with the Pachamama - the Earth - promoting relations of existence in a broad sense and reaffirming the sense of belonging to places and territories are not only forms of Amerindian differentiation in the face of Eurocentrism, but shared cosmopolitical perspectives, modes of alliance and construction to defend the common world, to reinhabit and share the planet. As Mbembe (2018) states, "Sharing the world with other living people, that is the debt par excellence. Here, above all, is the key to the durability of humans and nonhumans alike" (p. 311).

While political ecology, as a multi- and interdisciplinary paradigm and community of practice, rethinks itself to contribute to the understanding of undisciplined environments (ARMIERO et al., 2019), Amerindian, popular, quilombola, and peripheral political ecologies express the decolonial turn of this paradigm, promoting the emergence of voices that were silenced by the power and knowledge structures of coloniality. As Armiero et al. (2019) put it, political ecology is known to originate outside academia, "as a militant form of knowledge, with the aim of transforming the world and not only understanding it; a will that has persisted over the years and can still be found in most academic writings on political ecology."

The experience of the extractive reserves in Brazil arose precisely from the convergence of struggles, when the rubber tappers realized that what separated them from the indigenous people was the figure of the boss, and that they could live together with the forests. Organized in unions and collectives, they went from invisibility to representing "a paradigm of sustainable development with popular participation" (ALMEIDA, 2004, p. 33). In dialogue with this experience of counter-hegemonic conservation, socialist ecofeminism proposes a struggle to undo the Anthropocene. Instead of the paradigm of progress and development, an eco-socialist politics needs to recognize the relevance of the "forces of reproduction"-understood as subsistence labor, reproduction, regeneration, restoration, and care (BARCA, 2020).

Without fearing conflict, because it enables the construction of environmental justice, political ecologies dispute narratives and open paths of reflection and action. They understand the world by transforming it, but also by reconstructing and creating new worlds. And they do this from the territories, from the broadest struggles and disputes for hegemony to direct actions in local communities.

These political ecologies face a challenge in the current political moment, with the strengthening of climate change denial and post-truth in the service of authoritarian political agendas (NEIMARK, et al., 2019). In this context, it must be stressed that valuing alternative knowledges does not imply relativism - that is, asserting that any form of knowledge is as valid as the other. Political ecologies reaffirm knowledge positioned in the struggle against violence and exclusion in favor of socio-environmental justice, as 
well as recognize that modern science itself is a field in dispute. Facing the demonization of scientific knowledge promoted by reactionary movements, decolonial epistemologies play a key part in resisting authoritarian post-truth agendas and building alternatives. Thus, it is the role of political ecologies to expose how post-truth discourses emerge from hegemonic sectors that aim to reiterate exclusionary forms of knowledge and operate in well-known patterns of marginalization and oppression. As Neimark et al. (2019) state, "exposing unsubstantiated 'alt. facts' will not suffice (...). The role of political ecologists is to expose power, profit making, and threats to the environment and social justice" (p. 617). Subaltern sectors are precisely the most affected by the environmental degradation promoted by this discourse.

Political ecologies contribute to the vitality of an Earth-rooted thinking that challenges the hegemony of capitalist world-ecology. Countering the idea of isolated living, but affirming differences and similarities, they express political ontologies in "defense of other models of life" (ESCOBAR, 2017, p. 59). From the grassroots, in the territories, in the communities, in the collectives, in the places of life, from the borders and border thinking, at the margins of the universities' structures (ALIMONDA, 2017), overcoming the world-system of capitalist ecology means the defense of a common life on a shared planet that fits many worlds.

\section{References}

ACOSTA, A. Extrativismo e neoextrativismo: duas faces da mesma maldição In. DILGER, G.; LANG, M.; FILHO, J. (Coord.) Descolonizar o imaginário: debates sobre pós-extrativismo e alternativas ao desenvolvimento. São Paulo: Fundação Rosa Luxemburgo, p. 46-85, 2016.

ACSELRAD, H; MELLO, C.; BEZERRA, G. O que é justiça ambiental? Rio de Janeiro: Editora Garamond, 2009.

ALIMONDA, H. La colonialidad de la naturaleza: una aproximación a la Ecología Política Latinoamericana. In: ALIMONDA, Héctor (Coord.). La Naturaleza colonizada: ecología política y minería en América Latina. Buenos Aires, CLACSO, 2011.

ALIMONDA, H. Ecología política latinoamericana y pensamiento crítico: vanguardias arraigadas. Desenvolvimento e Meio Ambiente, v. 35, p. 161-168, 2015.

ALIMONDA H; PÉREZ C; MARTîN F. (Coord.) Ecología Política latino-americana: pensamento crítico, diferencia latino-americana y rearticulacíon epistémica. Buenos Aires: CLACSO. Vol 1 e Vol 2, 2017.

ALMEIDA, M. Direitos à floresta e ambientalismo: seringueiros e suas lutas. RBSC, v. 19, n. 55, p. 33-53, 2004. 
APIB (2021) Carta da Articulação dos Povos Indígenas do Brasil (APIB) a Joe Biden. Disponível em: https://apiboficial.org/files/2021/03/Carta-APIB-para-President-Biden_PORT_Original.pdf. Acesso em 16 de junho de 2021.

ARMIERO, M. et al. Undisciplining Political Ecology: A Minifesto. Undisciplined Environments, Online, 2019. Disponível em: https://undisciplinedenvironments.org/2019/10/01/undisciplining-political-ecology-a-minifesto/. Acesso em 24 de agosto de 2021.

ASCEMA. Cronologia de um desastre anunciado: ações do governo Bolsonaro para desmontar as políticas de meio ambiente no Brasil. Brasília: 2020.

BARCA, S. Forças de reprodução. O ecofeminismo socialista e a luta para desfazer o Antropoceno. E-cadernos CES, n. 34, p. 25-45, 2020.

BEBBINGTON, A. The New Extraction: Rewriting the Political Ecology of the Andes? NACLA Report on the Americas, v. 42, n. 5, p. 12-20, 2009.

BEBBINGTON, A. et al. Opinion: priorities for governing large-scale infrastructure in the tropics. PNAS, v. 117, n. 36, p. 21829-21833, 2020.

BERNABEU, M.; MARTÍN, F. El periurbano recreado. Urbanizaciones cerradas como nuevos híbridos en el paisaje hídrico del Área Metropolitana de Mendoza, Argentina. QUID 16, Buenos Aires, v.16, n.11, p. 55-85, 2019.

BOTERO-MESA, M. et al. La gestion comunitária del agua en Colombia en tiempos de pandemia covid-19. Medellin: Red Nacional de Acueductos Comunitarios de Colombia, 2020.

BRITTO, A.; FORMIGA-JOHNSSON, R.; CARNEIRO, P. Abastecimento público e escassez hidrossocial na metrópole do Rio de Janeiro. Ambiente e Sociedade, Campinas, v. XIX, n. 1, p. 185-207, 2016.

BUDDS, J.; MCGRANAHAN, G. Are the experiences on water privatization missing the point? Experiences from Africa, Asia and Latin America. Environment and Urbanization, Londres, v. 15, n.2, p. $87-113,2003$.

BROWN, W. In the ruins of neoliberalism: the rise of antidemocratic politics in the West. New York: Columbia University Press, 2019.

BUNKER, S. Underdeveloping the Amazon: extraction, Unequal Exchange, and the Failure of the Modern State. Chicago: The Chicago University Press, 1985.

CASTRO, J.; HELlER, L.; MORAIS, M. (Coord.) The Right to Water as Public Policy in Latin America: A theoretical and Empirical Exploration. Brasília: IPEA e WATERLAT-GOBACIT Network, 2015.

CLARK, E.; HERMELE, K. Financialisation of the environment: A literature review. Financialisation, Economy, Society \& Sustainable Development (FESSUD) Project Working Papers, (wpaper32), 2013. 
CORONIL, F. The magical state: Nature, money, and modernity in Venezuela. Chicago: University of Chicago Press, 1997.

CPT. Conflitos no Campo Brasil 2019. Goiânia: CPT Nacional, 2020.

DANOWSKY, D. Negacionismos. São Paulo: N-1 Edições, 2020.

DEONANDAN, K.; DOUGHERTY, L. Mining in Latin America: Critical Approaches to the New Extraction. New York, NY: Routledge, 2016.

EMPINOTTI, V.; BUDDS, J.; AVERSA, M. Governance and water security: the role of the water institutional framework in the 2013-15 water crisis in São Paulo, Brazil. Geoforum, Amsterdam, v. 98, pp: 46-54, 2019.

ESCOBAR, A. Encountering Development: The Making and Unmaking of the Third World. Princeton: Princeton University Press, 1995.

ESCOBAR, A. Desde abajo, por la izquierda, y con la tierra: la diferencia de Abya Yala/ Afro/ Latino/ América. In: ALIMONDA H; PÉREZ C, MARTîN F. (Coord.) Ecología Política latino-americana: pensamento crítico, diferencia latino-americana y rearticulacíon epistémica. Buenos Aires: CLACSO, 2017.

FAIRHEAD, J; LEACH, M; SCOONES L. Green grabbing: a new appropriation of nature? The Journal of Peasant Studies, v. 39, n. 2, p. 237-261, 2012.

FERRARA, L.; EMPINOTTI, V. Falta d'água e moradia popular na pandemia da Covid-19. São Bernardo do Campo: Universidade Federal do ABC, 2021.

GIRALDO, O.; ROSSET, P. Agroecology as a territory in dispute: Between institutionality and social movements. Journal of Peasant Studies, v. 45, n. 3, p. 545-564, 2017.

GLOBAL WITNESS. Defending Tomorrow. London, Global Witness, 2020.

GORZ, A. Ecologie une éthique de la libération. Interview. EcoRev, January 2006.

GROSFOGUEL, R. A estrutura do conhecimento nas universidades ocidentalizadas: racismo/sexismo epistêmico e os quatro genocídios/epistemicídios do longo século XVI. Revista Sociedade e Estado, v. 31, n. 1, p. 25-49, 2016.

GUDYNAS, E. Diez tesis urgentes sobre el nuevo extractivismo. Extractivismo, Política y Sociedad, Quito: CAAP e CLAES, 2009.

HARMES, A. The rise of neoliberal nationalism. Review of International Political Economy, v. 19, n. 1, p. 59-86, 2012.

HARVEY, D. O novo imperialismo. São Paulo: Edições Loyola, 2005.

HETCH, S. Environment, Development and Politics: Capital Accumulation and the Livestock 
Sector in Eastern Amazonia. World Development, Amsterdam, v. 13, n.6, p. 663 - 684, 1985.

KLINK, J.; EMPINOTTI, V.; AVERSA, M. On contested water governance and the making of urban financialisation: Exploring the case of metropolitan São Paulo, Brazil. Urban Studies, v. 57, n. 8, p. 1676-1695, 2020.

KRENAK, A. Ideias para adiar o fim do mundo. São Paulo: Cia. das Letras, 2019.

KRENAK, A.; BOLOGNESI, L. Os vencidos não se entregaram: entrevista com Ailton Krenak In. MILANEZ, F; SANTOS, F. Guerras da conquista: da invasão dos portugueses até os dias de hoje. Rio de Janeiro: Harper Collins, 2021.

LATOUR, B. A Europa como refúgio. In. GEISELBERGER, H. A grande regressão: um debate internacional sobre os novos populismos - e como enfrentá-los. São Paulo: Estação Liberdade, 2019.

LEFF, E. Ecologia Política: Da desconstrução do capital à territorialização da vida. Campinas: Editora UNICAMP, 2021.

LÉRY, J. Viagem à Terra do Brasil (1576). Belo Horizonte: Itatiaia, 2007.

MACHADO ARÁOZ, H. Mineração, Genealogia do Desastre: o Extrativismo na América. São Paulo: Editora Elefante, 2020.

MALERBA, J. Diferentes formas de dizer não: experiências internacionais de resistência, restrição e proibição ao extrativismo mineral. Rio de Janeiro: Fase, 2014.

MARTINEZ-ALIER, J. et al. Between activism and science: grassroots concepts for sustainability coined by Environmental Justice Organizations. Journal of Political Ecology, v. 21. n. 1, p. 19 $60,2014$.

MARTINEZ-ALIER, J. et al. Is there a global environmental justice movement? The Journal of Peasant Studies, v. 43, p. 731-755, 2016.

MARTINEZ-ALIER, J; MILANEZ, F. Ecologismo Dos Pobres, Colonialismo e Metabolismo Social. InSURgência: Revista de Direitos e Movimentos Sociais, v. 1, n. 2, p. 8-18, 2016.

MBEMBE, A. A Crítica da Razão Negra. São Paulo: N-1 Edições, 2018.

MILANEZ F. Cuerpo y alma del fascismo contemporáneo en Brasil: la ecología política del racismo y del extractivismo. Ecologia Política, v.59 - Julio, p. 17-23, 2020.

MILANEZ F.; SANTOS F. Guerras da Conquista: Da invasão dos portugueses até os dias de hoje. São Paulo, Harper Collins, 2021.

NAVARRO, M.; GUTIÉRREZ, R. Claves para pensar la interdependencia desde la ecología y los feminismos. Bajo el Volcán, Puebla, v.18, n. 28, p. 45-57, 2018. 
NEIMARK, B. et al. Speaking Power to "Post-Truth": Critical Political Ecology and the New Authoritarianism. Annals of the American Association of Geographers, Washington, v. 109, n.2, p. 613-623, 2019.

ONU. "Relatório do IPCC é um código vermelho para a humanidade". ONU News, online, 9 de agosto de 2021. Disponível em: https://news.un.org/pt/story/2021/08/1759292. Acesso em 24 de agosto de 2021.

PÁDUA, J. Um sopro de destruição: pensamento político e crítica ambiental no Brasil escravista (1786-1888). Rio de Janeiro: Jorge Zahar, 2002.

PEET, R.; WATTS, M. (Coord.). Liberation Ecologies: Environment, Development and Social Movements. 2. ed. Londres: Routledge, 2004.

PORTO-GONÇALVES, C.; LEFF, E. Ecologia Política na América Latina: reapropriação social da natureza, reinvenção de territórios e construção de uma racionalidade ambiental. In: LEFF, E. (Coord.). Ecologia Política - da desconstrução do capital à territorialização da vida. Campinas: Editora Unicamp, 2021, p. 429-468.

ROCA-SERVAT, D; PERDOMO-SÁNCHEZ, J. (Coord.) La Lucha por los Comunes Y las Alternativas al Desarrollo frente al Extractivismo. Buenos Aires: CLACSO, 2020.

SANTOS, A. Colonização, Quilombos, Modos e Significações. Brasília: INCTI/UnB, 2015.

SAUER, S.; LEITE, S. Expansão Agrícola, Preços e Apropriação de Terra por estrangeiros no Brasil. RESR, v. 50, n. 3, p. 503-524, 2012.

SEGATO, R.L. Contra-pedagogías de la crueldade. Buenos Aires: Prometeo, 2018.

STENGER, I. A proposição cosmopolítica. Revista do Instituto de Estudos Brasileiros, v. 69, p. 442-464, 2018.

SVAMPA, M. As fronteiras do neoextrativismo na América Latina: conflitos socioambientais, giro ecoterritorial e novas dependências. São Paulo: Editora Elefante, 2019.

SWYNGEDOUW, E; KAIKA, M. Urban Political ecology. Great Promises, Deadlock... and New Beginnings? Documents d'Anàlisi: Geogràfica, v. 60, n.3, p. 459-481, 2014.

VALE, M. et al. The COVID-19 pandemic as an opportunity to weaken environmental protection in Brazil. Biological Conservation, Amsterdam, v.255, p.1-5, 2021.

WOLFORD, W. et al. Governing Global Land Deals: The Role of the State in the Rush for Land. Development and Change, v. 44, n. 2, p. 189-210, 2017.

WORLD BANK. Rising global interest in farmland: Can it yield sustainable and equitable benefits? Washington D.C., 2010. 


\section{Vanessa Lucena Empinotti}

\v.empinotti@ufabc.edu.br

ORCiD: https://orcid.org/0000-0001-5789-6467
Submitted on: 07/09/2021

Accepted on: 09/09/2021 2021;24e:0160

\section{Sue A. S. Iamamoto}

$\checkmark$ sue.iamamoto@ufba.br

ORCiD: https://orcid.org/0000-0003-3918-0144

\section{Isabella Lamas}

凹isaalamas@unilab.edu.br

ORCiD: https://orcid.org/0000-0003-2145-1604

\section{Felipe Milanez}

$\checkmark$ felipemilanez@ufba.br

ORCiD: https://orcid.org/0000-0000-0003-4773-6691

How to cite: EMPINOTTI, V.L.; IAMAMOTO, S. A.S.; LAMAS, I; MILANEZ, F. Between crises and insurgencies: the political ecology in defense of a common life. Ambiente $\mathbb{\&}$ Sociedade. São Paulo, v. 24, p. 1-17, 2021. 


\title{
Entre crises e insurgências: a ecologia política em defesa da vida em comum
}

\author{
Vanessa Lucena Empinotti \\ Sue A. S. lamamoto \\ Isabella Lamas \\ Felipe Milanez
}

São Paulo. Vol. 24, 2021

Ideias em Debate: Insurgências Decoloniais e Horizontes Emancipatórios
Resumo: Neste artigo, desenvolvemos uma revisão de percursos recentes das ecologias políticas enquanto comunidades de práticas e movimentos por justiça ambiental, bem como um paradigma de análise científica. Ao introduzir o tema em destaque de 2021 da revista Ambiente e Sociedade "Insurgências Decoloniais e Horizontes Emancipatórios: contribuições da Ecologia Política", apresentamos uma reflexão sobre a realidade socioambiental contemporânea, marcada por crises, destruição ambiental e emergência climática, com foco no papel da ecologia política como um espaço privilegiado em discutir criticamente as relações socioambientais que se constituem em novas formas de apropriação violenta da natureza. Diante do quadro de tensão do contexto atual marcado pelo fortalecimento de fenômenos como o autoritarismo, o negacionismo e a desigualdade, ressaltamos a construção de contranarrativas e alternativas que mobilizam outros horizontes de emancipação e projetos de vida por meio de insurgências e movimentos que emergem do protagonismo de populações marginalizadas e das lutas por justiça ambiental.

Palavras-chave: Ecologia política; pensamento decolonial; relações socioambientais, apropriação da natureza; resistência

Como citar: EMPINOTTI, V.L.; IAMAMOTO, S. A. S.; LAMAS, I.; MILANEZ, F. Entre crises e insurgências: a ecologia política em defesa da vida em comum. Ambiente $\&$ Sociedade. São Paulo, v. 24, p. 1-17, 2021.

DOI: http://dx.doi.org/10.1590/1809-4422asoc20210160vu2021L5ID 


\title{
Entre crisis e insurgencias: la ecología política en defensa de la vida en común
}

\author{
Vanessa Lucena Empinotti \\ Sue A. S. lamamoto \\ Isabella Lamas \\ Felipe Milanez
}

São Paulo. Vol. 24, 2021

Ideas em Debate: Insurgencias Decoloniales y Horizontes Emancipatórios
Resumen: En este artículo, revisamos las trayectorias recientes de las ecologías políticas como comunidades prácticas y movimientos por justicia ambiental y como un paradigma académico. Introduciendo el tema destacado "Insurgencias Decoloniales y Horizontes Emancipatorios: contribuciones desde la Ecología Política”, presentamos una reflexión sobre la realidad socioambiental contemporánea, marcada por la crisis, la destrucción ambiental y la emergencia climática, centrándonos en el rol de la ecología política como espacio privilegiado para discutir críticamente las relaciones socioambientales que constituyen nuevas formas de apropiación violenta de la naturaleza. Frente a la tensión del contexto actual marcado por el fortalecimiento del autoritarismo, del negacionismo y de la desigualdad, destacamos la construcción de contranarrativas y alternativas que movilizan otros horizontes de emancipación y proyectos de vida a través de insurgencias y movimientos que surgen del protagonismo de las poblaciones marginadas y de las luchas por la justicia ambiental.

Palabras-clave: Ecología política; pensamiento decolonial; relaciones socioambientales, apropiación de la naturaleza; resistencia.

Como citar: EMPINOTTI, V.L.; IAMAMOTO, S. A.S.; LAMAS, I.; MILANEZ, F. Entre crisis e insurgencias: la ecología política en defensa de la vida en común. Ambiente $\&$ Sociedade. São Paulo, v. 24, p. 1-17, 2021.

DOI: http://dx.doi.org/10.1590/1809-4422asoc20210160vu2021L5ID 